DOI.

https://doi.org/10.22219/fths.v2i2

Received: Mei 2019

Accepted: Juni 2019

Available online: Juli 2019

\title{
Respon Penambahan Proporsi Bubur Rumput Laut Dengan Tepung Tapioka dan Konsentrasi Ekstrak Sawi Terhadap Mutu Bakso Ayam
}

\author{
Tri Mahdiyahtul Faricha1 ${ }^{1}$, Sri Winarsih ${ }^{2}$, Elfi Anis Saati ${ }^{*}$ \\ ${ }^{1}$ Program Studi Teknologi Pangan, Fakultas Pertanian Peternakan, Universitas Muhammadiyah \\ Malang, Malang, Indonesia \\ ${ }^{*}$ Corresponding author email: elfi@umm.ac.id
}

\begin{abstract}
Meatballs are round or other food products derived from cattle meat mix (not less than $50 \%$ meat content) and starch or cereals with or without the addition of other food ingredients and permissible dietary ingredients. Meatballs in general have a rubbery texture approaching hard and have a less attractive color that needs to be done production innovation, one of them is by addition of green mustard extract with the composition of seaweed porridge and tapioca flour. This study aims to determine the effect of interaction between the proportion of seaweed porridge with tapioca starch and extract concentration, and each of these factors. The research was conducted by using Group Random Design (RAK) two factors. Factor I with 4 levels is the composition of seaweed porridge with tapioca flour, among others: $5 \%: 25 \%, 10 \%: 20 \%, 15 \%: 15 \%, 20 \%: 10 \%$. Factor II with 3 levels is the addition of green mustard extract concentration (1:1, 2:1, 3: 1). Meatball testing is done on physicochemical properties (moisture content, ash, protein, fat, carbohydrate, antioxidant, total chlorophyll, texture and color) and organoleptic (taste, aroma, joy, suppleness, and appearance. The results showed that interaction between substitution of seaweed with green bean extract dye to moisture content, ash content, yellowishness $(b+)$, total chlorophyll, antioxidant, taste score, elasticity score, appearance score, and no effect on protein content, brightness (L), yellowishness (a-), aroma score, favorite score. The best treatment of chicken meatball was obtained from R4S3 treatment with the addition of 20\% seaweed porridge with $10 \%$ tapioca starch and 3: 1 green mustard concentration with $74.20 \%$ moisture content, $2.62 \%$ ash content, 2.53 fat content $\%$, protein content $17.45 \%$, carbohydrate $20.32 \%$, chlorophyll $0.47 \mathrm{mg} / \mathrm{L}$, and antioxidant $75.73 \%$, texture of 4.96 , brightness level $(L) 62.47$, yellowishness -) 7.07 , greenishness $(b+)$ 12.83. Furthermore, organoleptic test with organoleptic score 2.60 (enough), taste score 2.67 (good enough), aroma score 2.70 (quite like), score of 2.90 (quite interesting), and score suppleness 2.83 (quite chewy). All of parameters tested such as moisture content, ash content, protein content, and fat content have fulfilled SNI 01-3818 of 1995 chicken meatball.
\end{abstract}

Keywords: meatballs, green mustard extract, seaweed and tapioca flour

\section{PENDAHULUAN}

Bakso merupakan produk makanan berbentuk bulatan atau bentuk lain yang diperoleh dari campuran daging ayam (kadar daging tidak kurang dari 50\%) dan pati atau serealia dengan atau tanpa bahan tambahan 
makanan yang diizinkan (DSN, 1995) dan merupakan produk olahan daging yang merupakan bentuk emulsi yang disukai konsumen (Manullang dan Tanoto, 1995 dalam Iskandar 2004). Konsumsi bakso di Indonesia sangatlah besar, diperkirakan jumlah bakso per tahun dengan estimasi bahwa penduduk Indonesia di tahun 2008 adalah 238 juta dan masing-masing dari mereka mengkonsumsi sebutir bakso saja (Wibowo, 2010).

Komponen lemak di dalam produk olahan daging mempunyai peranan penting pada pembentukan tekstur, yaitu memberikan tekstur yang juiceness (empuk). Akan tetapi pada umumnya bakso yang dijual oleh para pedagang bakso mempunyai tekstur kenyal yang mendekati keras, hal ini disebabkan karena bakso tersebut menggunakan bahan baku tapioka yang cenderung mudah mengalami retrogradasi setelah pemasakan sehingga perlu adanya upaya perbaikan tekstur bakso yaitu dengan penambahan bahan - bahan kaya komponen hidrokoloid yang mampu memperangkap air lebih lama sehingga tekstur bakso kenyal tetap terjaga. Rumput laut merupakan salah satu bahan yang banyak mengandung komponen hidrokoloid yaitu karagenan. Karagenan tidak mempunyai nilai nutrisi dan digunakan pada makanan sebagai bahan pengental, pembuatan gel, dan emulsifikasi. Karagenan lebih stabil sebagai stabilitator bahan pengental pembentuk gel atau pengemulsi dibandingkan pengenyal lainnya (Winarno, 1997).

Selain tekstur bakso yang masih perlu diperbaiki penampilan bakso perlu dimodifikasi agar memiliki penampilan yang lebih menarik. Umumnya bakso berwarna coklat ke abu-abuan untuk sapi dan putih ke abu-abuan untuk bakso ayam. Bakso identik dengan produk tinggi protein dan lemak namun miskin akan serat dan antioksidan sehingga tertarik melakukan penelitian tentang formulasi filler dan pewarna untuk menghasilkan bakso dengan kualitas yang lebih baik. Oleh karena itu perlu ditambahkan ekstrak sawi untuk meningkatkan penampilan bakso sekaligus meningkatkan nilai gizi, dalam daun sawi hijau terdapat cukup banyak kandungan protein, mineral, kalsium, zat besi, vitamin A, vitamin C dan meningkatkan fungsional bakso. Sawi merupakan salah satu tanaman yang kaya antioksidan flavonoid (Kloppenburg, 2009).

Dalam proses penambahan ekstrak sawi, konsentrasi ekstrak yang ditambahkan akan mempengaruhi tampilan bakso itu sendiri, sehingga dirasa perlu dikaji proses ekstraksi sawi dengan perbandingan air dan sawi yang berbeda untuk menghasilkan konsentrasi ekstrak sawi yang tepat untuk diaplikasikan pada bakso. 


\section{METODE PENELITIAN}

\section{Bahan}

Bahan yang digunakan pada penelitian ini adalah tepung tapioka, rumput laut kering, sawi hijau, daging ayam bagian dada, bawang putih, garam,dan lada.

Alat

Alat-alat yang digunakan pada penelitian kali ini adalah tanur (Vurnace 48000), timbangan analitik merk pioneer ohaus, oven merk wic binder 7200 , waterbatch merk Digital Termostat,color reader (Konica Minolta), pnetrometer (Koehler). spectrofotometer UV Visible tipe UV-1800 merk SHIMADZU, spectrofotometer thermo spectronic merk GENESYS 20, texture analyzer model SM-500N-168.

\section{Pembuatan Bubur Rumput Laut}

Rumput laut kering direndam dengan air bersih selama 2 hari 3 malam, kemudian rumput laut selama 6 jam sekali diganti dengan air bersih. Rumput laut selama 2 hari ditambahkan air. Kemudian rumput laut yang setelah di rendam di blender sampai halus sehingga menjadi bubur rumput laut.

\section{Pembuatan Ekstrak Sawi Hijau}

Tanaman sawi hijau yang dibeli di pasar langsung dibersihkan dari kotorankotoran yang menempel dengan cara dicuci menggunakan air bersih terlebih dahulu. Kemudian memilih daun sawi hijau segar yang agak tua, kemudian memisahkan daun dari batangnya dan dipotong kecil - kecil, daun sawi hijau kemudian digiling menggunakan blender hingga halus dengan penambahan air $100 \mathrm{ml}$ selama dua menit. Kemudian pemisahan sari sawi hijau dan dimasukkan kedalam lemari pendingin.

\section{Pembuatan bakso berbahan dasar bubur rumput laut, tepung tapioka,} dan ekstrak sawi hijau

Tahap pembuatan bakso diawali dengan meninmbang daging $55 \mathrm{~g}$ yang sudah di fillet kemudian di blender sampai halus. Menimbang semua bahan-bahan sesuai dengan formulasi yang di tetapkan. Pencampuran semua bahan baku utama sesuai perlakuan yaitu bubur rumput laut dengan tepung tapioka, ditambahkan ekstrak pigmen sesuai perlakuan dan penambahan bahan pelengkap lain yaitu $2 \mathrm{~g}$ bawang putih, $2 \mathrm{~g}$ garam,dan $1 \mathrm{~g}$ lada, di homogenkan sampai adonan tercampur rata dan mudah dibentuk. Kemudian adonan dibentk bola - bola dan direbus direbus dalam air yang mendidih pada suhu 90 o C selama 10 menit sampai bakso mengapung dan didinginkan pada suhu ruang.

\section{Parameter Penelitian}

Parameter yang akan dilakukan untuk bahan baku (sawi dan ) yakni kadar air, abu, lemak, protein, karbohidrat, aktivitas antioksidan, dan total klorofil. 
Sedangkan untuk bakso, parameter penelitian yang dilakukan terdiri dari 3 jenis, yaitu uji fisik dan kimia meliputi kadar air,kadar protein, kadar abu, kadar lemak, karbohidrat, klorofil, dan uji DPPH (antioksidan), serta uji organoleptik.

\section{Rancangan Percobaan dan Analisa Data}

Penelitian ini dilakukan dengan menggunakan Rancangan Acak Kelompok (RAK) yang disusun secara faktorial dengan dua faktor. Faktor I adalah proporsi bubur rumput laut dan tepung tapioka, terdiri dari 4 level (5\% :25\%, 10\%:20\%, 15\%:15\%, dan 20\%:10\%) dan faktor II adalah konsentrasi ekstrak daun sawi (10\%) dengan perbandingan air terdiri dari 3 level (1:1, $2: 1$, dan $3: 1$ ) sehingga diperoleh 12 kombinasi perlakuan, dan ditambah dengan 1 perlakuan kontrol (tanpa perlakuan) yang diulang sebanyak 3 kali pengulangan.

Pengolahan data pada penelitian ini akan dilakukan dengan menggunakan metode rancangan kontras ortogonal, dengan menggunakan analisis ragam (ANOVA) pada taraf 5\%. Selanjutnya bila terjadi beda nyata atau interaksi pada masing -masing perlakuan maka data yang sudah diperoleh akan dilanjutkan dengan uji pembeda menggunakan uji DMRT (Duncan's Multiple Range Test) pada taraf $5 \%$.

\section{HASIL DAN PEMBAHASAN}

\section{Komposisi Kimia Bahan Baku}

Analisa bahan baku pada penelitian ini ini adalah rumput laut dan sawi hijau. Tujuan dari analisis bahan baku adalah untuk mengetahui kandungan kimia pada bahan sebelum dilakukan pengolahan maupun diaplikasikan pada sebuah produk olahan Hasil analisa bahan baku dapat dilihat pada Tabel 1.

Tabel 1 menunjukkan kualitas bahan baku yang diamati antara lain kadar air, kadar abu, kadar protein, kadar lemak, antioksidan, karbohidrat, dan total klorofil. Dari hasil uji bahan baku kadar air bubur rumput laut yaitu 71,91\%. Kadar air sangat penting pada produk, karena berkaitan dengan mutu dan daya simpan. Semakin sedikit kadar air pada suatu produk yang dihasilkan maka semakin baik mutunya, karena dapat menurunkan nilai aktivitas air (Aw) dan memperkecil potensi tumbuhnya mikroba yang dapat menurunkan mutu pada produk (Winarno, 2008). Kadar abu bubur rumput laut yang ditunjukan pada Tabel 1 yaitu 1,39\% kadar protein bubur rumput lau yaitu $2,4 \%$. Hal ini berarti bubur rumput laut memiliki kandungan protein yang tinggi sehingga baik untuk bahan tambahan sebagai pembuatan produk olahan pangan untuk meningkatkan nilai gizi (Hudaya, 2008). Kadar karbohidrat yaitu bubur rumput laut $23,97 \%$. 
Tabel 1. Komposisi kimia rumput laut, dan sawi hijau

\begin{tabular}{lcc}
\hline Parameter uji & Bubur rumput laut & Sawi Hijau \\
\hline Kadar Air (\%) & 71,91 & - \\
Kadar Abu (\%) & 1,39 & - \\
Kadar Protein (\%) & 2,04 & - \\
Kadar Lemak (\%) & 0,69 & - \\
KadarKarbohidrat (\%) & 23,97 & - \\
Aktivitas antioksidan (\%) & - & 78,32 \\
Kadar Total Klorofil (mg/L) & - & 6,50 \\
\hline
\end{tabular}

Berdasarkan hasil penelitian uji antioksidan pada bahan baku pewarna ekstrak sawi hijau yaitu sebesar 78,327 \%. Kandungan total klorofil dalam sayur sawi hijau yaitu 6,504 (mg/L). Klorofil diketahui berperan sebagai antioksidan bagi tubuh. Klorofil juga mampu berfungsi sebagai pembersih alamiah (mendorong terjadinya detoksifikasi) antioksidan yang akan menetralkan radikal bebas sebelum menimbulkan kerusakan pada sel-sel tubuh; antipenuaan dan antikanker (Tugiman dkk., 2007).

\section{Karakteristik Produk Bakso Ayam Kadar Air dan Kadar Abu.}

Berdasarkan analisis ragam diketahui bahwa terjadi interaksi antara perlakuan proporsi bubur rumput laut dengan tepung tapioka dan esktrak sawi hijau terhadap nilai kadar air, kadar abu bakso ayam. Rerata nilai masingmasing perlakuan dapat dilihat pada Tabel 2.

Berdasarkan Tabel 2 menunjukkan bahwa rerata kadar air bakso ayam yang tertinggi pada kadar air terdapat pada perlakuan proporsi bubur rumput laut $20 \%$ dan tepung tapioka 10\% dan konsentrasi ekstrak sawi 3:1 yaitu 74,55\%. Hal ini disebabkan oleh sumbangan air yang berasal dari rumput laut Eucheuma cottoni semakin banyak. Selain itu kenaikan kadar air juga disebabkan karena semakin meningkatnya kadar protein seiring dengan bertambahnya penggunaan rumput laut Eucheuma cottoni dan semakin sedikitnya tapioka. Menurut Prince dan Schweigert (1971) dalam Iskandar (2004), protein merupakan substansi pengikat air paling penting, dengan bertambahnya protein pada bakso maka ikatan protein-air akan kuat, sehingga lepasnya air dari jaringan dapat dicegah sehingga kadar air bakso dapat dipertahankan. Kadar air semakin meningkat dengan penambahan es ekstrak sawi hijau. Hal ini sesuai dengan pendapat Direktorat gizi, Departemen Kesehatan RI (2012) bahwa kandungan kadar air didalam sawi hijau yaitu $92,2 \%$.

Kadar abu tertinggi pada proporsi bubur rumput laut 15\% dan tepung tapioka 15\%, Ekstrak sawi 1:1. Hal ini dipengaruhi oleh garam mineral yang terkandung dalam esktrak sawi dan rumput laut Eucheuma cottoni yang 
ditambahkan dalam formula bakso. Menurut Sudarmadji dkk (1996), kadar abu ada hubungannya dengan mineral suatu bahan.

Tabel 2. Rerata kadar air dan kadar abu bakso ayam pada perlakuan proporsi bubur rumput laut dengan tepung tapioka dan konsentrasi esktrak sawi.

\begin{tabular}{|c|c|c|c|}
\hline \multicolumn{2}{|c|}{ Perlakuan } & \multirow[b]{2}{*}{ Kadar Air (\%) } & \multirow[b]{2}{*}{ Kadar Abu (\%) } \\
\hline $\begin{array}{c}\text { Rumput Laut: Tepung } \\
\text { Tapioka }\end{array}$ & $\begin{array}{c}\text { Ekstrak } \\
\text { Sawi }\end{array}$ & & \\
\hline Kontrol ( $0: 30)$ & - & $61,69 \mathrm{a}$ & 1,67 a \\
\hline R1S1 $\quad(5: 30)$ & $1: 1$ & $66,40 \mathrm{~b}$ & $1,84 \mathrm{a}$ \\
\hline R2S1 $\quad(10: 20)$ & $1: 1$ & $66,43 \mathrm{~b}$ & $2,32 \mathrm{ab}$ \\
\hline R3S1 (15:15) & $1: 1$ & $69,63 \mathrm{c}$ & $2,66 \mathrm{~b}$ \\
\hline R4S1 $\quad(20: 10)$ & $1: 1$ & $73,00 \mathrm{~cd}$ & $2,63 \mathrm{~b}$ \\
\hline R1S2 ( $5: 25)$ & $2: 1$ & $68,82 \mathrm{bc}$ & 1,72 a \\
\hline R2S2 $\quad(10: 20)$ & $2: 1$ & $70,35 \mathrm{c}$ & $2,00 \quad \mathrm{a}$ \\
\hline R3S2 (15:15) & $2: 1$ & $71,30 \mathrm{c}$ & $2,07 \quad \mathrm{a}$ \\
\hline$(20: 10)$ & $2: 1$ & $74,55 \mathrm{~d}$ & $2,20 \mathrm{ab}$ \\
\hline$(5: 25)$ & $3: 1$ & $66,06 \mathrm{~b}$ & 1,77 a \\
\hline R2S3 (10:20) & $3: 1$ & $66,39 \mathrm{~b}$ & $1,94 \quad \mathrm{a}$ \\
\hline$(15: 15)$ & $3: 1$ & $73,97 \mathrm{~cd}$ & $2,20 \mathrm{ab}$ \\
\hline R4S3 $\quad(20: 10)$ & $3: 1$ & $74,20 \mathrm{~cd}$ & $2,62 \quad \mathrm{~b}$ \\
\hline
\end{tabular}

Nilai rata-rata yang diikuti oleh huruf yang sama, tidak berpengaruh nyata menurut Uji Duncan $\alpha=5 \%$

\section{Kadar Protein}

Berdasarkan analisis ragam menunjukkan bahwa tidak terjadi interaksi anatara proporsi bubur rumput laut dengan tepung tapioka dan konsentrasi esktrak sawi hijau yang ditambahkan, namun secara terpisah berpengaruh sangat nyata terhadap kadar protein bakso ayam yang dihasilkan.

Berdasarkan hasil yang diperoleh dapat dilihat pada Tabel 3, bahwa hasil penelitian menunjukkan bahwa kadar protein bakso. Nilai kadar protein bakso dengan penambahan substitusi tapioka dengan rumput laut Eucheuma cottoni hasil penelitian berkisar antara 9,57 \% sampai 11,16\%. Kenaikan kadar protein bakso yang disebabkan oleh peningkatan penambahan jumlah rumput laut Eucheuma cottoni yang digunakan. Menurut penelitian Erikson (2013), bahwa kadar protein pada bakso hasil subtistusi tapioka, sagu dengan rumput laut menigkat dengan berkurangnya tepung dan bertambanhnya jumlah rumput laut yang digunakan. 
Tabel 3. Rerata kadar protein bakso ayam pada perlakuan proporsi bubur rumput laut dengan tepung tapioka dan konsentrasi esktrak sawi.

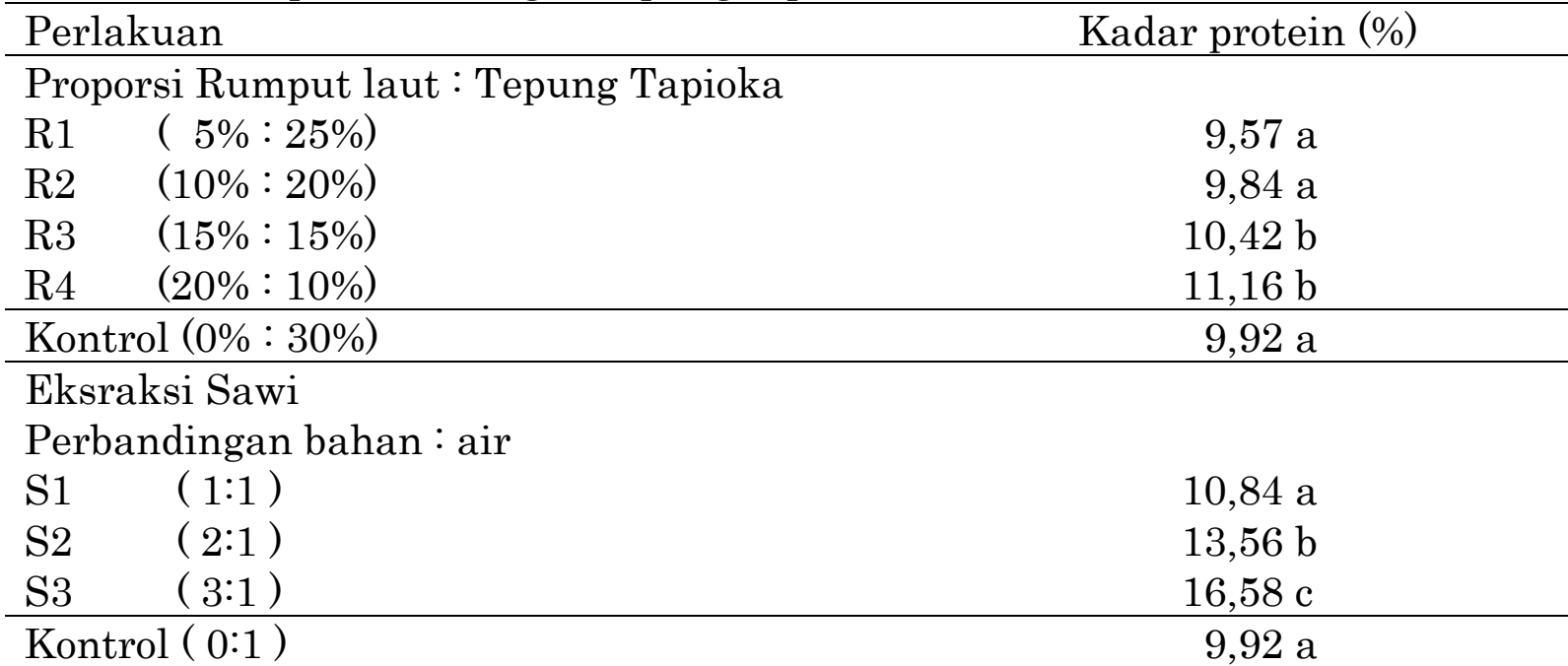

Nilai rata-rata yang diikuti oleh huruf yang sama, tidak berpengaruh nyata menurut Uji Duncan $a=5 \%$

Sedangkan dengan penambahan konsentrasi ekstrak sawi semakin banyak konsentrasi yang ditambahkan semakin tinggi juga hasil protein yang didapatkan. Kadar protein tertinggi dihasilkan dengan penambahan ekstrak dengan perbandingan 3:1 (S3). Hal ini dikarenakan bahan baku pembuatan bakso ayam yang berasal dari ekstrak sawi memiliki kandungan kadar protein sebesar 2,3\% sehingga semakin banyak penggunaan ekstrak sawi hijau meningkatkan protein bakso ( Direktorat Gizi, Departemen Kesehatan RI, 2012).

\section{Kadar Lemak}

Berdasarkan analisis ragam menunjukkan bahwa terdapat pengaruh sangat nyata pada perlakuan antara proporsi bubur rumput laut dengan tepung tapioka terhadap kadar lemak bakso ayam. Hasil rerata kadar lemak terhadap proporsi bubur rumput laut dengan tepung tapioka dapat dilihat pada Tabel 4 .

Tabel 4. Rerata kadar lemak bakso pada perlakuan proporsi bubur rumput laut dengan tepung tapioka

\begin{tabular}{lcc}
\hline & Perlakuan & Kadar lemak (\%) \\
\hline P1 & $(5 \%: 25 \%)$ & $1,48 \mathrm{a}$ \\
R2 & $(10 \%: 20 \%)$ & $1,59 \mathrm{~b}$ \\
R3 & $(15 \%: 15 \%)$ & $1,75 \mathrm{~b}$ \\
R4 & $(20 \%: 10 \%)$ & $1,88 \mathrm{~b}$ \\
\hline Kontrol $(0 \%: 30 \%)$ & $1,59 \mathrm{~b}$ \\
\hline
\end{tabular}

Nilai rata-rata yang diikuti oleh huruf yang sama, tidak berpengaruh nyata menurut Uji Duncan $\alpha=5 \%$ 
Pada Tabel 4. menunjukan bahwa kadar lemak tertinggi pada perlakuan R4 sebesar $1,86 \%$ dikarenakan semakin banyaknya rumput laut yang ditambahkan maka akan menghasilkan lemak yang banyak. Hal ini sesuai dengan penelitian Yani (2006), bahwa kadar lemak tinggi pada bubur rumput laut yaitu $0,37 \%$ dibandingkan kadar lemak tepung tapioka yaitu 0,3\%. Penggunan rumput laut Eucheuma cottoni yang semakin banyak meningkatkan kestabilan emulsi pada bakso.

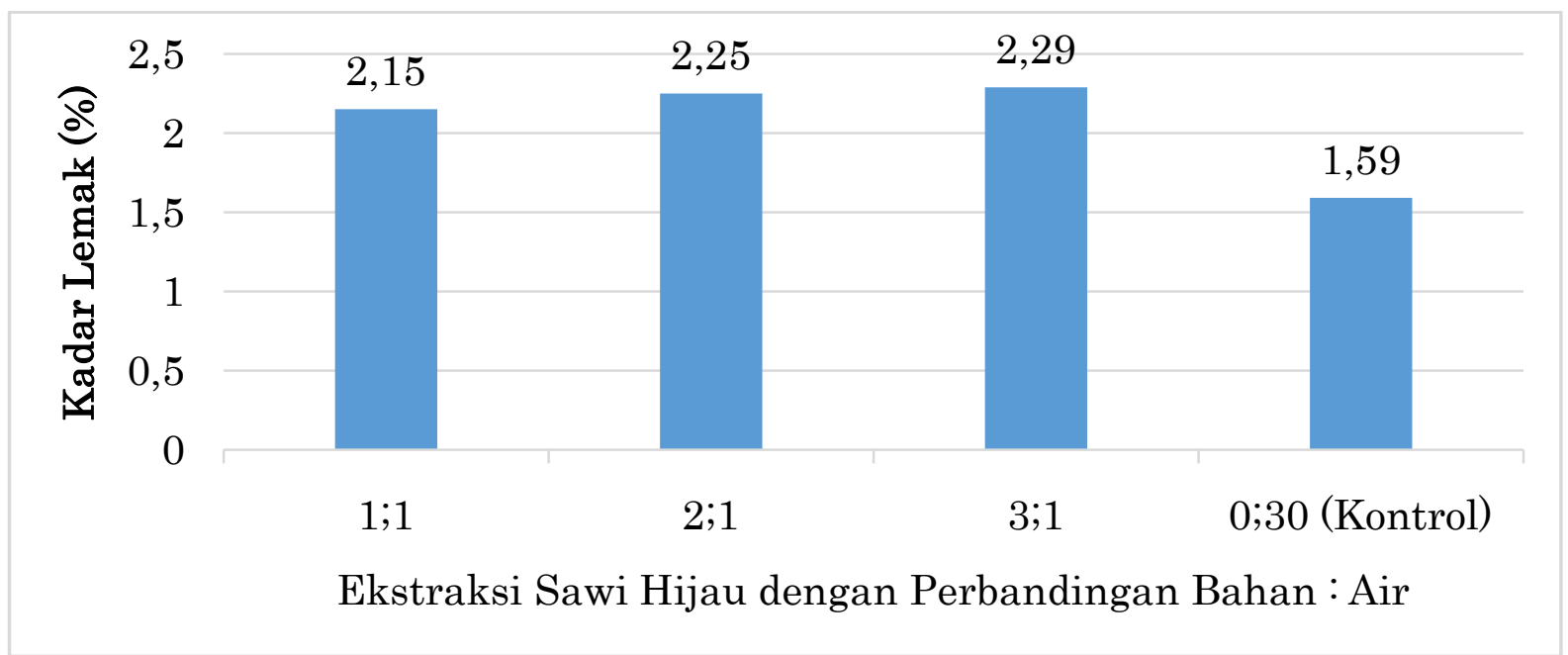

Gambar 1. Grafik rata-rata kandungan kadar lemak bakso berdasarkan perbedaan konsentrasi penambahan konsentrasi ekstrak sawi yang berbeda.

Berdasarkan Gambar 1, dapat dilihat bahwa konsentrasi penambahan pewarna ekstrak sawi hijau tidak memberikan pengaruh nyata terhadap kandungan kadar lemak bakso ayam. Hal ini disebabkan karena kandungan lemak pada sawi sebesar 0,4 gr per 100 gr (Direktorat Gizi, Departemen Kesehatan RI, 2012). Oleh sebab itu penambahan ekstrak sawi hijau dengan konsentrasi yang berbeda tidak memberikan pengaruh nyata terhadap kadar lemak terhadap bakso ayam.

\section{Kadar Karbohidrat dan Aktivitas Antioksidan}

Berdasarkan analisis ragam diketahui bahwa terjadi interaksi antara perlakuan proporsi bubur rumput laut dengan tepung tapioka dan esktrak sawi hijau terhadap nilai kadar karbohidrat dan antioksidan bakso ayam. Rerata nilai masing-masing perlakuan dapat dilihat pada Tabel 5 .

Kadar karbohidrat yang tertinggi pada perlakuan Kontrol yaitu 25,145\%. Hal ini dipengaruhi oleh semakin banyak penggunaan ekstrak sawi hijau akan menghasilkan karbohidrat yang banyak, karbohidrat pada sawi hijau sebanyak 4,0gr (Direktorat Gizi, Departemen Kesehatan RI 2012) dan semakin banyak tepung tapioka maka karbohidrat pada bakso akan semakin meningkat dan jika semakinbanyaknya rumput laut yang digunakan maka semakin sedikit 
kandungan karbohidrat yang terkandung dalam bakso, dikarenakan kandungan tepung tapioka lebih besar dari pada rumput laut yaitu 86,9\% (Anonim, 2009)

Tabel 5. Rerata kadar karbohidrat dan antioksidan bakso ayam proporsi bubur rumput laut dengan tepung tapioka dan konsentrasi esktrak sawi.

\begin{tabular}{|c|c|c|c|}
\hline \multicolumn{2}{|c|}{ Perlakuan } & \multirow[b]{2}{*}{$\begin{array}{c}\text { Kadar Karbohidrat } \\
(\%)\end{array}$} & \multirow{2}{*}{$\begin{array}{c}\text { Antioksidan } \\
(\%)\end{array}$} \\
\hline $\begin{array}{c}\text { Rumput Laut: Tepung } \\
\text { Tapioka }\end{array}$ & $\begin{array}{l}\text { Ekstrak } \\
\text { Sawi }\end{array}$ & & \\
\hline Kontrol ( $0: 30)$ & - & $25,14 \mathrm{f}$ & $20,46 \mathrm{a}$ \\
\hline$(5: 30)$ & $1: 1$ & $12,01 \mathrm{ab}$ & $27,13 \mathrm{~b}$ \\
\hline R2S1 $\quad(10: 20)$ & $1: 1$ & $11,13 \mathrm{ab}$ & $29,19 \mathrm{bc}$ \\
\hline$(15: 15)$ & $1: 1$ & $11,00 \mathrm{a}$ & $32,37 \mathrm{c}$ \\
\hline$(20: 10)$ & $1: 1$ & $10,96 \mathrm{a}$ & $34,06 \mathrm{~cd}$ \\
\hline$(5: 25)$ & $2: 1$ & $18,90 \mathrm{~d}$ & $34,29 \mathrm{~cd}$ \\
\hline$(10: 20)$ & $2: 1$ & $15,12 \mathrm{c}$ & $34,70 \mathrm{~cd}$ \\
\hline$(15: 15)$ & $2: 1$ & $14,95 \mathrm{c}$ & $36,71 \mathrm{~d}$ \\
\hline$(20: 10)$ & $2: 1$ & $12,28 \mathrm{~b}$ & $41,51 \mathrm{e}$ \\
\hline$(5: 25)$ & $3: 1$ & $21,24 \mathrm{e}$ & $43,88 \mathrm{e}$ \\
\hline$(10: 20)$ & $3: 1$ & $20,71 \mathrm{de}$ & $49,49 \mathrm{f}$ \\
\hline$(15: 15)$ & $3: 1$ & $20,32 \mathrm{de}$ & $68,09 \mathrm{~g}$ \\
\hline$(20: 10)$ & $3: 1$ & $19,67 \mathrm{~d}$ & $75,73 \mathrm{~h}$ \\
\hline
\end{tabular}

Nilai rata-rata yang diikuti oleh huruf yang sama, tidak berpengaruh nyata menurut Uji Duncan $a=5 \%$

Kadar antioksidan tertinggi pada proporsi rumput laut $20 \%$ dan tepung tapioka 10\%, Ekstrak sawi $2: 1$ dengan jumlah 75,73\%. Penambahan konsentrasi ekstrak sawi hijau yang semakin tinggi akan juga meningkatkan kandungan antioksidan dalam bakso ayam. Menurut Reische (2002) yang menyatakan beberapa senyawa antioksidan akan lebih aktif apabila dipanaskan karena peranannya dalam reaksi pencoklatan nonenzimatis. Hal tersebut yang menjadi alasasan tingginya kandungan senyawa antioksidan pada sayursayuran jika melalui pemanasan. Selain itu Sawi hijau merupakan salah satu tanaman yang kaya antioksidan flavonoid, indoles, sulforaphane, karoten, lutein dan zeaxanthin. Daun sawi segar juga kaya akan vitamin $\mathrm{C}$ dan vitamin A (Kloppenburg, 2009).

\section{Total Klorofil dan Tekstur}

Berdasarkan analisis ragam diketahui bahwa terjadi interaksi antara perlakuan proporsi bubur rumput laut dengan tepung tapioka dan esktrak sawi hijau terhadap nilai Total Klorofil dan Tekstur bakso ayam. Rerata nilai masingmasing perlakuan dapat dilihat pada Tabel 6. 
Tabel 6. Rerata Total klorofil dan Tekstur bakso ayam pada perlakuan proporsi bubur rumput laut dengan tepung tapioka dan konsentrasi esktrak sawi.

\begin{tabular}{|c|c|c|c|c|}
\hline \multicolumn{3}{|c|}{ Perlakuan } & \multirow[b]{2}{*}{$\begin{array}{l}\text { Total Klorofil } \\
\text { (mg/L) }\end{array}$} & \multirow[b]{2}{*}{ Tekstur (N) } \\
\hline \multicolumn{2}{|c|}{$\begin{array}{c}\text { (Rumput Laut: Tepung } \\
\text { Tapioka) }\end{array}$} & Ekstrak Sawi & & \\
\hline Kontro & $1(0: 30)$ & & $0,02 \mathrm{a}$ & $3,95 \mathrm{a}$ \\
\hline R1S1 & $(5: 30)$ & $1: 1$ & $0,18 \mathrm{~b}$ & $7,20 \mathrm{~d}$ \\
\hline $\mathrm{R} 2 \mathrm{~S} 1$ & $(10: 20)$ & $1: 1$ & $0,19 \mathrm{~b}$ & $5,55 \mathrm{bc}$ \\
\hline R3S1 & $(15: 15)$ & $1: 1$ & $0,22 \mathrm{~b}$ & $5,40 \mathrm{bc}$ \\
\hline $\mathrm{R} 4 \mathrm{~S} 1$ & $(20: 10)$ & $1: 1$ & $0,24 \mathrm{bc}$ & $4,58 \mathrm{ab}$ \\
\hline R1S2 & $(5: 25)$ & $2: 1$ & $0,26 \mathrm{bc}$ & $7,02 \mathrm{~d}$ \\
\hline $\mathrm{R} 2 \mathrm{~S} 2$ & $(10: 20)$ & $2: 1$ & $0,26 \mathrm{bc}$ & $5,76 \mathrm{c}$ \\
\hline R3S2 & $(15: 15)$ & $2: 1$ & $0,29 \mathrm{bc}$ & $4,62 \mathrm{ab}$ \\
\hline $\mathrm{R} 4 \mathrm{~S} 2$ & $(20: 10)$ & $2: 1$ & $0,30 \mathrm{c}$ & $4,14 \mathrm{a}$ \\
\hline R1S3 & $(5: 25)$ & $3: 1$ & $0,31 \mathrm{c}$ & $7,24 \mathrm{~d}$ \\
\hline $\mathrm{R} 2 \mathrm{~S} 3$ & $(10: 20)$ & $3: 1$ & $0,34 \mathrm{c}$ & $6,17 \mathrm{~d}$ \\
\hline R3S3 & $(15: 15)$ & $3: 1$ & $0,44 \mathrm{~d}$ & $5,67 \mathrm{bc}$ \\
\hline $\mathrm{R} 4 \mathrm{~S} 3$ & $(20: 10)$ & $3: 1$ & $0,47 \mathrm{~d}$ & $4,96 \mathrm{~b}$ \\
\hline
\end{tabular}

Nilai rata-rata yang diikuti oleh huruf yang sama, tidak berpengaruh nyata menurut Uji Duncan $a=5 \%$

Rerata kadar total klorofil tertinggi diperoleh pada perlakuan proporsi bubur rumput laut $20 \%$ dan tepung tapioka 10\%, Ekstrak sawi $3: 1$ yaitu 0,47 $\mathrm{mg} / \mathrm{L}$, total klorofil semakin meningkat dengan semakin meningkatnya penambahan konsentrasi ekstrak sawi dan bubur rumput laut. Peningkatan kadar total klorofil dalam bakso disebabkan karena ekstrak sawi hijau memiliki kandungan klorofil yang lebih tinggi. Begitupula penambahan bubur rumput laut juga mempengaruhi nilai kadar total klorofil. Hal ini sesuai dengan pendapat Marquez et al., 2005 klorofil dan turunannya yang mengikat logam mempunyai kapasitas antioksidan dan biovalabilitas yang berbeda. $\mathrm{Cu}$-klorofilin sebagai salah satu turunan klorofil mempunyai aktivitas antioksidan yang lebih tinggi dibandingkan klorofil alami.

Rerata nilai tekstur tertinggi diperoleh pada perlakuan proporsi bubur rumput laut 5\% dengan tapioka 25\% Ekstrak sawi 3: 1, yaitu 7,24\%. Hal ini menunjukkan bahwa semakin besar yang dihasilkan menunjukkan tekstur semakin keras yang disebabkan penambahan bubur rumput laut, dan menambahnya kadar air pada ekstrak sawi hijau sehingga tekstur menjadi lembek, secara umum kadar air meningkat dengan semakin meningkatnya konsentrasi sawi (Triyantini, 1998).

\section{Organoleptik Rasa}

Berdasarkan analisis ragam diketahui bahwa terjadi interaksi antara perlakuan proporsi bubur rumput laut dengan tepung tapioka dan esktrak sawi 
hijau terhadap rasa bakso yang dihasilkan. Rerata nilai organoleptik rasa disajikan pada Tabel 7.

Tabel 7. Rerata skor rasa bakso pada perlakuan proporsi bubur rumput laut dengan tepung tapioka dan konsentrasi ekstrak sawi

\begin{tabular}{|c|c|c|}
\hline \multicolumn{2}{|l|}{ Perlakuan } & \multirow[b]{2}{*}{ Skor Rasa } \\
\hline $\begin{array}{c}\text { Proporsi Rumput Laut: Tepung } \\
\text { Tapioka }\end{array}$ & istrak sawi & \\
\hline Kontrol $(0: 30)$ & - & $3,27 \mathrm{~b}$ \\
\hline R1S1 ( $5: 30)$ & $1: 1$ & $2,67 \mathrm{a}$ \\
\hline R2S1 $\quad(10: 20)$ & $1: 1$ & $2,63 \mathrm{a}$ \\
\hline R3S1 (15:15) & $1: 1$ & $2,63 \mathrm{a}$ \\
\hline R4S1 $\quad(20: 10)$ & $1: 1$ & $2,73 \mathrm{a}$ \\
\hline R1S2 ( $5: 25)$ & $2: 1$ & $3,47 \mathrm{~b}$ \\
\hline$(10: 20)$ & $2: 1$ & $2,80 \mathrm{a}$ \\
\hline$(15: 15)$ & $2: 1$ & $2,60 \mathrm{a}$ \\
\hline$(20: 10)$ & $2: 1$ & $2,80 \mathrm{a}$ \\
\hline$(5: 25)$ & $3: 1$ & $2,60 \mathrm{a}$ \\
\hline$(10: 20)$ & $3: 1$ & $2,60 \mathrm{a}$ \\
\hline R3S3 (15:15) & $3: 1$ & $2,43 \mathrm{a}$ \\
\hline R4S3 $\quad(20: 10)$ & $3: 1$ & $2,47 \mathrm{a}$ \\
\hline
\end{tabular}

Nilai rata-rata yang diikuti oleh huruf yang sama, tidak berpengaruh nyata menurut Uji Duncan $\alpha=5 \%$

Skor $=1:$ Sangat tidak enak $3:$ Cukup Enak $\quad 5:$ Sangat Enak

2: Tidak enak $\quad 4:$ Enak

Berdasarkan hasil yang diperoleh dapat dilihat pada Tabel 7 menunjukkan rerata nilai organoleptik rasa tertinggi diperoleh pada perlakuan proporsi bubur rumput laut 5\% dengan tepung tapioka 25\% dan konsentrasi ekstrak sawi 1:1 yaitu degan skor 3,47. Pada dasarnya rasa merupakan faktor penentu daya terima konsumen terhadap produk pangan. Menurut Surjana (2001), umumnya ada tiga macam rasa yang sangat menentukan penerimaan konsumen yaitu kegurihan, keasinan, dan rasa daging.

\section{Organoleptik Aroma}

Berdasarkan hasil analisa ragam diketahui bahwa perlakuan proporsi bubur rumput laut dengan tepung tapioka dan konsentrasi esktrak sawi hijau tidak berpengaruh terhadap aroma bakso yang dihasilkan. Rerata tingkat aroma bakso ayam ditampilkan pada Gambar 2.

Analisa organoleptik rasa semakin banyak penambahan rumput laut yang digunakan panelis tidak menyukai aroma dari bakso ayam. Nilai aroma juga dipengaruhi oleh selera panelis terhadap bakso ayam, dan dapat dilihat dari nilai reratanya bahwa panelis sangat menyukainya bau aroma dari bakso ayam 
dengan penambahan ekstrak sawi semakin sedikit. Karena aroma dari ekstrak sawi semakin banyak akan menyebabkan aroma langu panelis kurang meyukai

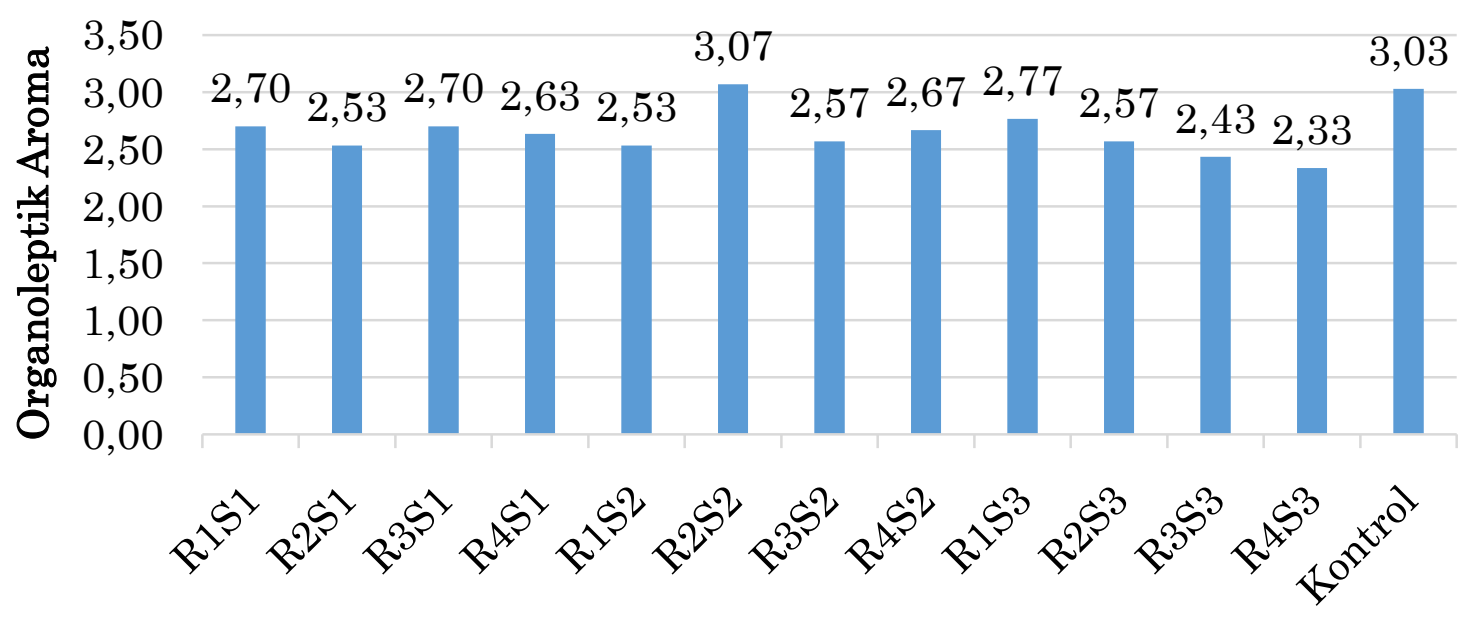

\section{Perlakuan}

Gambar 2. Grafik rerata skor aroma pada proporsi bubur rumput laut dengan tepung tapioka dan konsentrasi ekstrak sawi

Keterangan :

R1S1 : Bubur rumput laut + tepung tapioka $(5 \%+25 \%) \&$ ekstrak sawi $1: 1$

R2S1 : Bubur rumput laut + tepung tapioka $(10 \%+20 \%)$ \& ekstrak sawi $1: 1$

R3S1 : Bubur rumput laut + tepung tapioka $(15 \%+15 \%)$ \& ekstrak sawi 1:1

R4S1 : Bubur rumput laut + tepung tapioka $(20 \%+10 \%)$ \& ekstrak sawi 1:1

R1S2 : Bubur rumput laut + tepung tapioka $(5 \%+25 \%)$ \& ekstrak sawi $2: 1$

R2S2 : Bubur rumput laut + tepung tapioka $(10 \%+20 \%)$ \& ekstrak sawi $2: 1$

R3S2 : Bubur rumput laut + tepung tapioka $(15 \%+15 \%)$ \& ekstrak sawi $2: 1$

R4S2 : Bubur rumput laut + tepung tapioka $(20 \%+10 \%)$ \& ekstrak sawi $2: 1$

R1S3 : Bubur rumput laut + tepung tapioka $(5 \%+25 \%)$ \& ekstrak sawi 3:1

R2S3 : Bubur rumput laut + tepung tapioka $(10 \%+20 \%)$ \& ekstrak sawi $3: 1$

R3S3 : Bubur rumput laut + tepung tapioka $(15 \%+15 \%)$ \& ekstrak sawi $3: 1$

R4S3 : Bubur rumput laut + tepung tapioka $(20 \%+10 \%)$ \& ekstrak sawi $3: 1$

Skor Rasa:

1: Sangat tidak enak $3:$ Cukup enak $5:$ Sangat Enak

2: Tidak enak

$4:$ Enak

Penambahan perlakuan pada bakso ayam tidak berpengaruh nyata karena perlakuan proporsi bubur rumput laut dengan tepung tapioka dan esktrak sawi hijau bukan salah satu tanaman rempah yang mengandung atsiri sehingga tidak menimbulkan aroma yang khas. Mutu aroma dapat dipengaruhi oleh jumlah penggunaan bumbu dan komposisi ayam dalam pembuatan bakso. Hal ini sesuai dengan menurut Hui, et al, (2001) bahwa penggunaan bumbu pada produk pangan bertujuan untuk memberikan aroma pada produk pangan tersebut. Komponen bumbu seperti bawang putih mengandung zat pangan seperti anilinyang menyumbangkan rasa dan aroma pada bakso. 


\section{Organoleptik Kesukaan}

Berdasarkan analisis ragam diketahui bahwa perlakuan proporsi bubur rumput laut dengan tepung tapioka dan konsentrasi esktrak sawi hijau tidak berpengaruh terhadap organoleptik kesukaan bakso yang dihasilkan.Rerata tingkat organoleptik kesukaan bakso ayam ditampilkan pada Gambar 3.

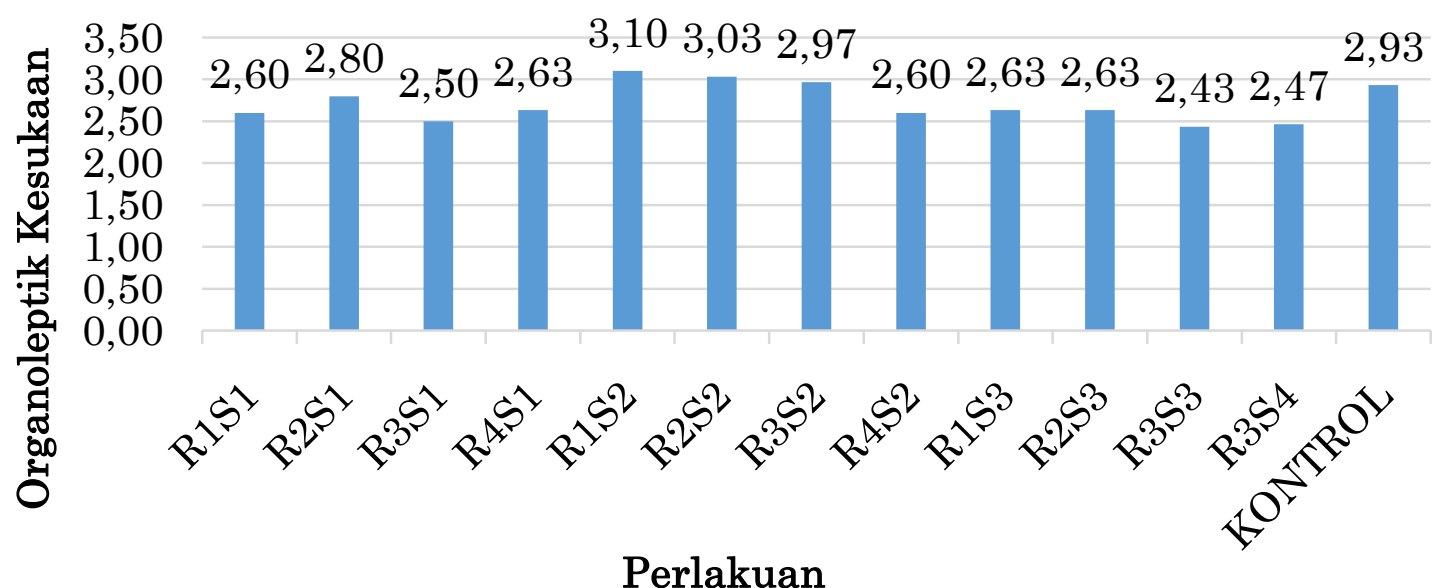

Gambar 3. Grafik rerata skor kesukaan pada proporsi bubur rumput laut dengan tepung tapioka dan konsentrasi ekstrak sawi

Keterangan :

R1S1 : Bubur rumput laut + tepung tapioka $(5 \%+25 \%)$ \& ekstrak sawi 1:1

R2S1 : Bubur rumput laut + tepung tapioka $(10 \%+20 \%)$ \& ekstrak sawi 1:1

R3S1 : Bubur rumput laut + tepung tapioka $(15 \%+15 \%) \&$ ekstrak sawi 1:1

R4S1 : Bubur rumput laut + tepung tapioka $(20 \%+10 \%) \&$ ekstrak sawi $1: 1$

R1S2 : Bubur rumput laut + tepung tapioka $(5 \%+25 \%)$ \& ekstrak sawi $2: 1$

R2S2 : Bubur rumput laut + tepung tapioka $(10 \%+20 \%)$ \& ekstrak sawi $2: 1$

R3S2 : Bubur rumput laut + tepung tapioka $(15 \%+15 \%)$ \& ekstrak sawi $2: 1$

R4S2 : Bubur rumput laut + tepung tapioka $(20 \%+10 \%)$ \& ekstrak sawi $2: 1$

R1S3 : Bubur rumput laut + tepung tapioka $(5 \%+25 \%)$ \& ekstrak sawi $3: 1$

R2S3 : Bubur rumput laut + tepung tapioka $(10 \%+20 \%)$ \& ekstrak sawi $3: 1$

R3S3 : Bubur rumput laut + tepung tapioka $(15 \%+15 \%)$ \& ekstrak sawi $3: 1$

R4S3 : Bubur rumput laut + tepung tapioka $(20 \%+10 \%) \&$ ekstrak sawi $3: 1$

Skor kesukaan :

1: Sangat tidak suka 3: Cukup Suka 5: Sangat Suka

2: Tidak suka $\quad 4:$ Suka

Berdasarkan hasil yang diperoleh dapat dilihat pada Gambar 3, menunjukkan bahwa rerata skor kesukaan pada panelis memberikan suatu penilaian tertinggi pada perlakuan penambahan bubur rumput laut $5 \%$ dengan tepung tapioka $25 \%$ dan ekstrak sawi 2:1. Berdasarkan hasil data tersebut menunjukkan bahwa tingkat kesukaan panelis semakin menurun dengan bertambahnya proporsi bubur rumput laut dengan tepung tapioka dan konsentrasi ekstrak sawi. 
Tingkat kesukaan panelis selain dilihat dari rasa juga dilihat dari parameter aroma, tekstur, dan warna. Aroma yang enak dan gurih membuat daya tarik panelis meningkat, begitu pula dengan terkstur dan warna, warna bakso yang menarik membuat daya tarik panelis, menurut Winarno (2004), menyatakan bahwa warna merupakan salah satu atribut penampilan pada suatu produk yang seringkali menentukan tingkat penerimaan konsumen terhadap produk tersebut secara keseluruhan.

\section{Organoleptik Kenampakan dan Kekenyalan}

Berdasarkan analisis ragam diketahui bahwa terjadi interaksi antara perlakuan proporsi bubur rumput laut dengan tepung tapioka dan konsentrasi ekstrak sawi terhadap organoleptik skor kenampakan dan skor kekenyalan bakso yang dihasilkan. Rerata nilai masing-masing perlakuan dapat dilihat pada Tabel 8.

Tabel 8. Rerata skor kenampakan dan skor kekenyalan bakso ayam pada perlakuan proporsi bubur rumput laut dengan tepung tapioka dan konsentrasi esktrak sawi.

\begin{tabular}{|c|c|c|c|}
\hline \multicolumn{2}{|c|}{ Perlakuan } & \multirow{2}{*}{$\begin{array}{c}\text { Skor } \\
\text { Kenampakan }\end{array}$} & \multirow{2}{*}{$\begin{array}{c}\text { Skor } \\
\text { Kekenyalan }\end{array}$} \\
\hline $\begin{array}{c}\text { Rumput Laut: Tepung } \\
\text { Tapioka }\end{array}$ & $\begin{array}{l}\text { Ekstrak } \\
\text { Sawi }\end{array}$ & & \\
\hline Kontrol $(0: 30)$ & - & $3,53 \mathrm{c}$ & $3,03 \mathrm{ab}$ \\
\hline R1S1 $\quad(5: 30)$ & $1: 1$ & $3,57 \mathrm{c}$ & $2,97 \mathrm{ab}$ \\
\hline$(10: 20)$ & $1: 1$ & $2,50 \mathrm{a}$ & $2,77 \quad \mathrm{a}$ \\
\hline R3S1 $\quad(15: 15)$ & $1: 1$ & $2,60 \mathrm{a}$ & $3,33 \mathrm{ab}$ \\
\hline$(20: 10)$ & $1: 1$ & $2,53 \mathrm{a}$ & $2,53 \mathrm{a}$ \\
\hline$(5: 25)$ & $2: 1$ & $2,83 \mathrm{ab}$ & $2,93 \mathrm{ab}$ \\
\hline$(10: 20)$ & $2: 1$ & $2,97 \mathrm{ab}$ & $2,87 \quad \mathrm{a}$ \\
\hline$(15: 15)$ & $2: 1$ & $2,67 \mathrm{ab}$ & $3,00 \mathrm{ab}$ \\
\hline$(20: 10)$ & $2: 1$ & $2,57 \mathrm{a}$ & $2,57 \mathrm{a}$ \\
\hline$(5: 25)$ & $3: 1$ & $3,07 \mathrm{~b}$ & $3,07 \mathrm{ab}$ \\
\hline$(10: 20)$ & $3: 1$ & $3,37 \mathrm{bc}$ & $2,97 \mathrm{ab}$ \\
\hline$(15: 15)$ & $3: 1$ & $2,90 \mathrm{ab}$ & $2,80 \quad \mathrm{a}$ \\
\hline$(20: 10)$ & $3: 1$ & $2,43 \mathrm{a}$ & $2,83 \quad \mathrm{a}$ \\
\hline
\end{tabular}

Nilai rata-rata yang diikuti oleh huruf yang sama, tidak berpengaruh nyata menurut Uji Duncan $\alpha=5 \%$

Skor $=1:$ Sangat tidak menarik/ sangat tidak kenyal

2 : Tidak menarik/ Tidak kenyal

3 : Cukup menarik/ Cukup kenyal

$4:$ Menarik/Kenyal

5 : Sangat Menarik/ Sangat Kenyal

Pada perlakuan bubur rumput laut 5\% dan tepung tapioka 25\% dengan konsentrasi ekstrak sawi 1:1 panelis lebih menyukainya, diakibatkan penggunaan ekstrak sawi yang semakin sedikit memberikan warna yang lebih menarik, dan 
penggunaan rumput laut tidak terlalu banyak. Hal ini sesuai dengan pendapat Yusuf (2012) tingkat penerimaan konsumen terhadap penampakan suatu produk bukan hanya dilihat dari warna, akan tetapi bentuk dan keseragaman ukuran secara visual juga berpengaruh.

Penambahan proporsi bubur rumput laut dengan tepung tapioka dan konsentrasi ekstrak sawi terjadi interaksi terhadap kekenyalan bakso ayam, hal ini dikarenakan penambahan bubur rumput laut dengan tepung tapioka yang dapat mengikat kadar air (Iskandar, 2004) dan sebagai pengenyal dalam bahan makanan memiliki proporsi yang pas sehingga kekenyalan dari bakso ayam dapat diterima oleh konsumen.

\section{KESIMPULAN}

Perlakuan terbaik bakso ayam dipeoleh dari perlakuan R4S3 dengan penambahan proporsi bubur rumput laut 20\% dengan tepung tapioka $10 \%$ dan konsentrasi ekstrak sawi hijau 3:1 dengan nilai kadar air 74,20\%, kadar abu 2,62\%, kadar lemak 2,53\%, kadar protein 17,45\%, kadar karbohidrat 20,32\%, klorofil 0,47 mg/L, dan antioksidan 75,73\%, analisa tekstur sebesar 4,96 analisa warna L 62,47, analisa warna $a^{-} 7,07$, analisa warna b+ 12,83. Selanjutnya juga dilakukan uji organoleptik dengan hasil organoleptik skor kesukaan 2,60 (cukup suka), skor rasa 2,67 (cukup enak), skor aroma 2,70 (cukup suka), skor kenampakan 2,90 (cukup menarik), dan skor kekenyalan 2,83 (cukup kenyal). Dari semua parameter yang diujikan seperti kadar air, kadar abu, kadar protein, dan kadar lemak sudah memenuhi SNI 01-3818 tahun 1995 bakso ayam.

\section{REFERENSI}

Anonim, 2009. Pangan untuk Indonesia. Siteresource.worldbank.org [02 Desember 2009]. Diakses tanggal 2 Oktober 2015.

Direktorat Gizi Departemen Kesehatan (dalam Rukmana 1994, hal 14) Direktorat Gizi Depkes RI, 1996. Daftar Komposisi Bahan Makanan. Bhratara Karya Aksara, Jakarta.

Kloppenburg, 2009. Petunjuk Lengkap mengenai Tanam - tanaman di Indonesia dan Khasiatnya sebagai Obat - obatan Tradisisonal. Yogyakarta:Yayasan Dana Sejahtera.

Marques., F, 2005. Antioxidant activity of chlorophylls and their derivates. Food Research International 38, 885-891.

Margiyanto, E, 2007. Hortikultura. Bantul : Cahaya Tani.

Sudarmadji, S, 1996. Prosedur Analisa untuk Bahan Makanan dan Pertanian. Penerbit Liberty, Yogyakarta

Tugiman, S, 2007. Pengaruh pengantian daging sapi dengan daging kerbau, ayam dan kelinci,pada komposisi dan kualitas bakso. Laporan Penelitian Fakultas Peternakan, Universitas Gadjah Mada, Yogyakarta 
Wibowo, L \& Fitriyani. E, 2012. Pengolahan Rumput Laut Eucheuma Cottoni Menjadi Serbuk Minuman Instan. Jurusan Ilmu Kelautan dan Perikanan. Politeknik Negeri Pontianak. Jurnal Vokasi. 8(2): 101- 109.

Winarno, F.G, 1997. Pangan, Gizi, Teknologi dan Konsumen. Gramedia. Jakarta. Winarno, F.G, 2004. Kimia Pangan Dan Gizi. Gramedia Puataka Utama. Jakarta Yusuf, R. R, 2002. Formulasi, Karakteristik Kimia, dan Uji Aktivitas Antioksidan Produk Minuman Fungsional Tradisional Sari Jahe (Zingiber officinale Rosc.) dan Sari Sereh Dapur (Cymbopogan flexuosus). Bogor: IPB. 